\section{Fremskritt i glattcellen}

Politidirektoratet opprettet 19.2. 2002 «Politiarrestprosjektet», med overlege Willy Aasebø som medisinsk rådgiver. Gruppen avga en rapport allerede 27. juni samme år. Året etter ble det publisert en artikkel i Tidsskriftet som viste at 36 personer døde i glattcelle i landets politiarrester i perioden 1993-2001 (1), altså et gjennomsnitt på fire hvert år.

Undersøkelsen er nå gjentatt, denne gangen for perioden 2003-12 (2). Rapporteringen viser at det var 11 dødsfall i denne perioden, gjennomsnittlig ett hvert år. Opplysningene er sjekket mot tilgjengelige kilder. Funnet er robust. Det er blitt langt færre «tragedier i glattcellen» (3). Hva er årsaken? Rusmiddelbruken i samfunnet er ikke blitt mindre, heller ikke voldsnivået. Kan det være at vi møter problemene bedre?

Etter Politiprosjektet er det kommet flere reformer. Politiloven $\S 9$ har fått skjerpede bestemmelser om legetilsyn (4). Når en beruset person er ute av stand til å ta vare på seg selv eller å gjøre rede for seg, skal politiet straks vurdere overføring til medisinsk institusjon. Skjer det ikke, skal vedkommende ha legetilsyn ved innbringelsen. Er det tegn på skade eller hvis det er andre grunner til at personen trenger helsetilsyn, skal politiet straks tilkalle lege eller annet helsepersonell. I påvente av overføring til sykehus eller gjennomføring av lege- eller helsetilsyn skal den innbrakte ha skjerpet tilsyn av politiet. Dersom den innbrakte ber om det, skal politiet formidle kontakt med lege eller annet helsepersonell.

I 2006 kom det dessuten en egen forskrift om bruk av politiarrest (5). Forskriften regulerer et eget arresttilsyn. Hver politimester er ansvarlig for inspeksjon av og tilsyn i arresten. I tillegg er en sentral inspeksjon underlagt Politidirektoratet. Tilsynsrapporteringene skal oversendes Spesialenheten for politisaker. Enheten skal etterforske alle dødsfall $\mathrm{i}$ arresten. Ansvaret for helsetjenesten er lagt til kommuneoverlegen, uten kostnad for politiet. Det er innført en ordning med opplæring av spesialtjenestemenn, «arrestforvaltere». I tillegg er det utviklet et databasert journalsystem og skriftlige instrukser for inspeksjon og mulighet til lyd- og bildeoverføring fra arrestene.

Aasebø og medarbeidere viser at antall dødsfall på grunn av alkoholforgiftning etter dette er redusert fra 11 av 36 i den første perioden til ett av $11 \mathrm{i}$ den andre, mens antall dødsfall med hodeskader er gått fra fem til ingen (2). Den sannsynlige årsaken er at helsevesenet har fått en langt mer sentral plass, slik det ble anbefalt av Aasebø og medarbeidere allerede i 2001 (6). Antall dødsfall på grunn av andre forgiftninger er imidlertid nær uendret. Den sannsynlige årsaken er at rutinene ikke fanger opp faren for slike overdoseringer.

Det er grunn til å merke seg dødsfall med funn av metadon, som brukes i legemiddelassistert rehabilitering ved opioidavhengighet (LAR). Dette stoffet har en langsom metabolisering, og blandingsforgiftninger kan derfor utvikles gradvis. I utredningen Et ansvarlig politi (7) beskrives et slikt tilfelle - en arrestant døde på tross av 16 tilsyn fra polititjenestemann. Heyerdal og medarbeidere har vist hvorledes forgiftninger bør behandles profesjonelt og nyansert slik at arrestanter med farlige intoksikasjoner kan selekteres til innleggelse og andre få nødvendig ambulant behandling (8).
Et annet viktig moment er at arresten i den siste perioden i mindre grad er brukt med hjemmel i politiloven $\S 9$ om innbringelse av berusede personer og relativt sett mer med straffeprosessuelle begrunnelser for arrestasjon og varetekt. Selv om beruselse fremdeles har medvirket til innbringelsen ved for eksempel husbråk, betyr dette at avsløringer av kriminelle forhold, kriser med dårlig kontrollert atferd og liknende er en vesentlig årsak. Slike arrestanter vil kunne være personer i livskriser med depressivt innhold, og i slike tilfeller er glattcellen ikke noe egnet sted. Suicid er nå den nest vanligste dødsårsaken.

Aasebø og medarbeidere har gitt oss en viktig analyse og viser positivt samspill mellom samfunnsengasjement og forskning. Det har vært et fruktbart samarbeid med justissektoren, som har gjennomført systematiske reformer på et komplisert område. En vesentlig del av glattcelletragediene er derfor forhindret.

Noe står likevel igjen, spesielt når det gjelder overdoser med medikamenter og illegale rusmidler og mennesker i krise. Disse problemene trenger nye løsninger. Én vei kan være mer omhyggelig screening før innsetting. Et styrket legetilsyn kan gi noen svar. Andre må finnes i bedre opplæring i arresttilsyn. Eksistensielle kriser kan være vanskelig å oppdage og vanskelig å intervenere i. Politiarrestutvalget brukte begrepet «risikoarrestanter» og foreslo mulighet for lyd- og bildeovervåking. Dette er blitt sterkt begrenset etter innvendinger fra blant annet Sivilombudsmannen. Det er grunn til å vurdere om denne muligheten bør utnyttes bedre.

Vi er kommet et stykke på vei mot trygghet i glattcellen, men målet er fortsatt noen skritt unna.

Helge Waal

helge.waal@medisin.uio.no

Helge Waal (f. 1940) er professor emeritus ved Universitetet i Oslo og overlege i bistilling ved Avdeling for rus- og avhengighetsbehandling. Oslo universitetssykehus. Han har mangeårig klinisk erfaring innen psykiatri og rusbehandling og har vært sentral innen klinisk rusforskning i Norge.

Forfatter har fylt ut ICMJE-skjemaet og oppgir ingen interessekonflikter.

\section{Litteratur}

1. Aasebø W, Erikssen J, Jonsbu J. Dødsfall i norske politiarrester. Tidsskr Nor Lægeforen 2003; 123: 1066-7.

2. Aasebø W. Orskaug G, Erikssen J. Dødsfall i norske politiarrester 2003-12. Tidsskr Nor Legeforen 2014; 134: $291-4$

3. Waal H. Tragedier i glattcellen. Tidsskr Nor Lægeforen 2003; 123: 1047.

4. Ot.prop. nr. 61 (2003-2004). Om lov om endringer i politiloven (vurdering av helsetilstanden ved innsetting i arrest, politimyndighet, Politihøgskolen mv.

FOR 2006-06-30-749. Forskrift om bruk av politiarrest.

6. Aasebø W. Erikssen J, Jonsbu J. Akutt alkoholforgiftning i sykehus og fyllearrest. Tidsskr Nor Lægeforen 2001; 121: 2683-5.

7. Norges offentlige utredninger. Et ansvarlig politi. Åpenhet, kontroll og læring. NOU 2009: 13

8. Heyerdahl F, Bjornaas MA, Dahl R et al. Repetition of acute poisoning in Oslo: 1-year prospective study. Br J Psychiatry 2009; 194: 73-9. 